TECHNICAL TEACHER TRAINING AND CERTIFICATION ACCORDING TO THE IGIP SYSTEM

Julia Ziyatdinova, 


\title{
TECHNICAL TEACHER TRAINING AND CERTIFICATION ACCORDING TO THE IGIP SYSTEM
}

\author{
V. Prikhodko, L. Petrova, T. Polyakova, A. Solovyev
}

\begin{abstract}
The paper describes the scheme for training, advanced training and retraining of engineering teachers in the Training Centers of the International Society for Engineering Pedagogy (IGIP). It focuses on the design of educational programs for different levels, the creation of learning and teaching materials, and the organization of certification procedure for teachers at international level. Particular attention is paid to the modular principle of study programs design.

Introduction

The Russian Federation is taking part in the creation of European Higher Education Area (EHEA). An important aspect of this work is harmonization of the requirements for the pedagogical staff of technical universities and colleges (engineering teachers) by means of international cooperation and experience exchange. In the past twenty years many Russian technical universities have been engaged in collaboration with the International Society for Engineering Pedagogy (IGIP). About 100 Russian technical higher school teachers are members of IGIP. Annually 10-20 of them take part in the IGIP conferences where they present their papers and participate in the interchange of views.

IGIP system of training centers

The most important part of IGIP's activity is training and certification of engineering teachers. Below we shall describe both aspects. Preparation of teachers is institutionalized in special IGIP Training Centers (TC) that are situated in many countries. In Russia a TC is usually called the Center of Engineering Pedagogy (CEP) [1]. Each TC must be once accredited by IGIP and then reaccredited every 5 years. Now there are 35 accredited TCs all over the world and 14 of them are in Technical Universities located in different regions of Russia (Fig.).
\end{abstract}

For being certified an engineering teacher must have a diploma of an engineer, a TC diploma and have teaching experience not less than 1 year. After certification by the IGIP International Monitoring Committee (IMC) the applicant is awarded the title of International Engineering Educator (ING-PAED IGIP). The TC diploma indicates graduation from a special course in one of the TCs accredited by IGIP. At present there are 383 teachers from Russian Technical Universities awarded the title ING-PAED IGIP and they are included in IGIP Register. These teachers form the main reserve for the pedagogical staff of TCs.

\section{IGIP Curriculum}

International cooperation allows IGIP to elaborate effective curriculum (Table) and up-to-date teaching and learning materials for training and retraining engineering teachers who improve their competences [2]. 


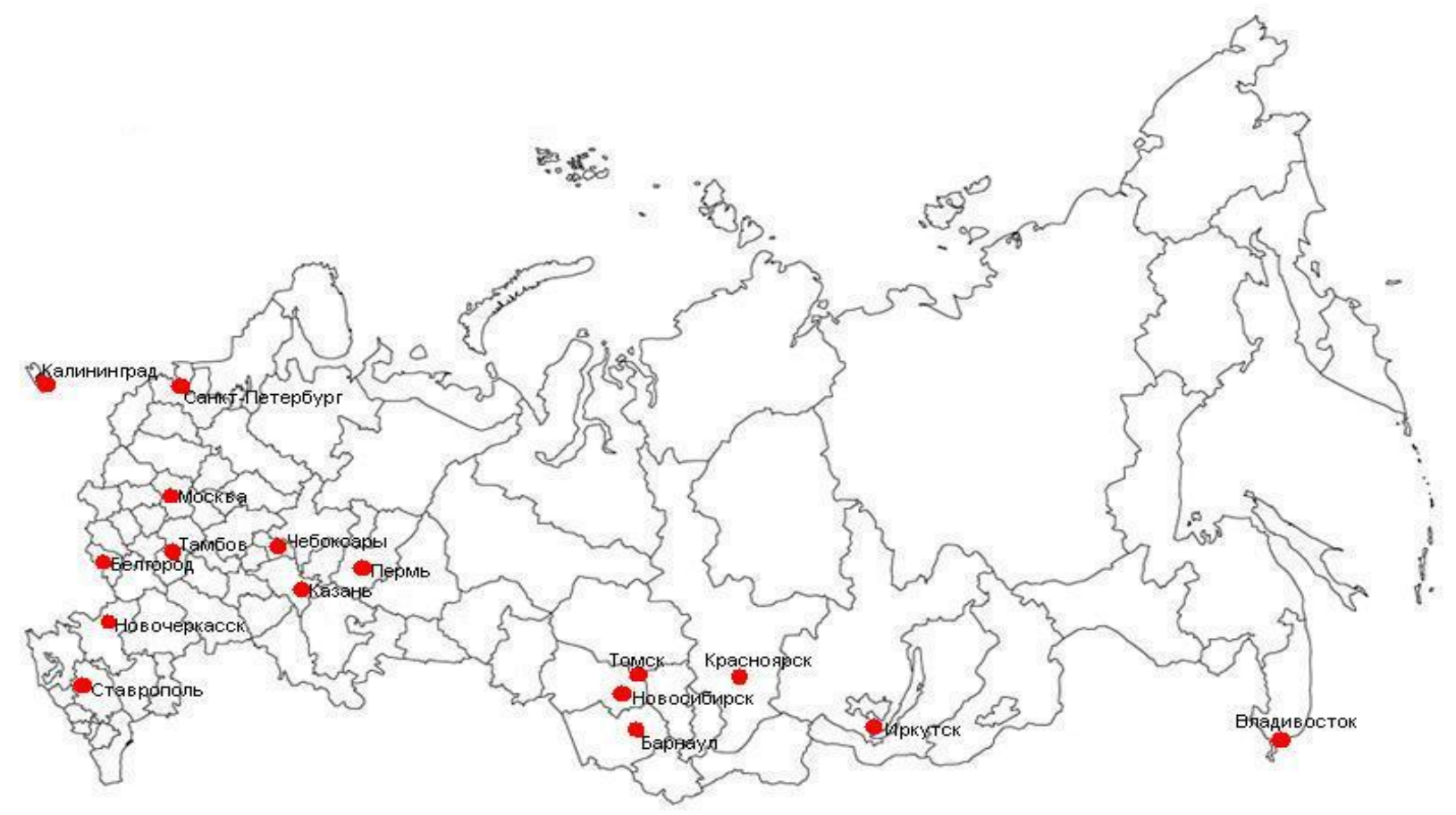

Fig. Russian Network of Engineering-Pedagogical Education

The modular design allows varying the curriculum according to different categories of trainees. The curriculum can be modified for training engineering master students in parallel with their basic studies. The curriculum can be used also for the purposes of Life Long Learning (LLL). In this case it means training of those who have just graduated from technical universities or retraining and improving the quality of the persons who are already engineering teachers. The modular design allows also to vary the curriculum according to the peculiarities of different countries. Two other reports of the ASEE Forum agenda are devoted to the introduction of IGIP system in Russia.

Table. IGIP TC Curriculum

\begin{tabular}{|l|l|l|}
\hline & Module Description & $\begin{array}{l}\text { Credit Points (at } \\
\text { least) }\end{array}$ \\
\hline & Core Modules & $\mathbf{7}$ \\
\hline M1 & Engineering Education in Theory & 2 \\
\hline M2 & Engineering Education in Practice & 3 \\
\hline M3 & Laboratory Didactics & 2 \\
\hline & Theory Modules & $\mathbf{5}$ \\
\hline M4 & Psychology & 2 \\
\hline M5 & Sociology & 1 \\
\hline M6 & Engineering Ethics & 1 \\
\hline M7 & Intercultural Competence & 1 \\
\hline & Practice Modules & $\mathbf{5}$ \\
\hline M8 & Presentation and Communication Skills & 2 \\
\hline
\end{tabular}




\begin{tabular}{|l|l|l|}
\hline & Module Description & $\begin{array}{l}\text { Credit Points (at } \\
\text { least) }\end{array}$ \\
\hline M9 & Scientific Writing & 1 \\
\hline M10 & Working with Projects & 1 \\
\hline M11 & ICT in Engineering Education & 1 \\
\hline & $\begin{array}{l}\text { Elective Modules (1 CP per subject) } \\
\text { (choose any three of eight) }\end{array}$ & $\mathbf{3}$ \\
\hline EM1 & Evaluation of Student Performance & 1 \\
\hline EM2 & Quality Management & 1 \\
\hline EM3 & Portfolio Assessment & 1 \\
\hline EM4 & Creative Thinking & 1 \\
\hline EM5 & Coaching and Mentoring in Education & 1 \\
\hline EM6 & Collaborative Work & 1 \\
\hline EM7 & Teaching Subject in English & 1 \\
\hline EM8 & Infoliteracy & 1 \\
\hline & Total & 20 \\
\hline
\end{tabular}

The first manual for engineering teacher training was written by the founder of IGIP A. Melezinek [3]. This book was written in German and then translated in a number of foreign languages. International cooperation helps to prepare new teaching and learning materials. Many important modern teaching materials were prepared in the course of the Tempus-projects of the European Commission:

1. Dissemination of Pedagogical Innovation of Engineering Education in Russian and Ukrainian Universities/ Tempus-Project DIERUU, European Commission, 2002-2004.

2. Teachers Training on Electronic Manual Development/ Tempus-Project TREM, European Commission, 2005-2006.

3. Curriculum Development of Multimedia Course for Russian and Ukrainian EngineerPedagogical Education/ Tempus-Project MULTICEP, European Commission, 2004-2007. 4. Innovative Language Curricula in Technical Universities/ Tempus-Project ILAN, European Commission, 2007-2009.

5. Online Quality Assurance of Study Programmes (EQUASP) 543727-TEMPUS-1-2013-1-ITTEMPUS-SMGR (2011-2503/001-001), 2014-2016.

\section{Conclusions}

The Russian Federation has been engaged in the development of the European Higher Education Area since signing the Bologna Declaration in 2003. It caused the necessity of forming standard requirements to the teaching programs of engineering education and to qualification level of universities teachers as well as to mechanisms of their certification. In this situation the activity of IGIP and its national monitoring committees is of great importance. As it was shown IGIP system plays an important role in this process for Russian higher technical education. It contributes to the experience exchange and dissemination of advanced innovations in engineering pedagogy. 


\section{Bibliography}

[1] Prikhodko, V., Solovyev, A. (2013) [IGIP and trends of Engineering Education in Russia and in the world]. Vysshee obrazovanie v Rossii [Higher education in Russia]. No.6, pp.26-32. (in Russ., abstract in Eng.)

[2] Prikhodko, V., Solovyev, A. (2013) Training of international engineering educators according to the new IGIP curriculum. Proceedings of 2013 16th International Conference on Interactive Collaborative Learning, ICL 2013; Kazan; Russian Federation; 25 September 2013 through 27 September 2013. pp. 299-305.

[3] Melezinek, A. Ingenieurpaedagogik, Springer Verlag Wien, New York, 3, Aufl. (In German) 